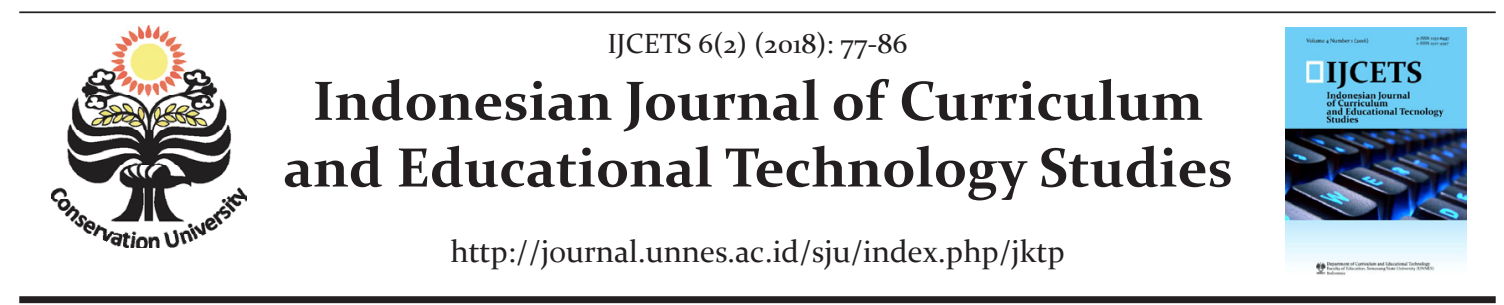

\title{
EFL Students' Use of Technology in English Lesson in The Digital Era
}

\author{
Anggi Arigusman, ${ }^{1} \otimes$ Pupung Purnawarman, ${ }^{1}$ Didi Suherdi ${ }^{1}$ \\ ${ }^{\circledR}$ Program Pascasarjana, Universitas Pendidikan Indonesia, Bandung, Indonesia \\ DOI: https://doi.org/10.15294/ijcets.v6i2.26599
}

\section{Article History}

Received : August, 2018 Accepted : Oktober 2018

Published : November 2018

\section{Keywords}

EFL students; English lesson; use of technology; internet

\begin{abstract}
Abstrak
Berbagai informasi dan ilmu pengetahuan termasuk pelajaran bahasa Inggris dapat diakses dengan mudah. Hal itu memberikan kesempatan yang besar pada siswa untuk memanfaatkan teknologi guna meningkatkan kemampuan bahasa Inggris mereka. Namun kebanyakan siswa EFL sepertinya lebih cenderung memanfaatkan teknologi untuk sekedar hiburan daripada untuk mengasah bahasa Inggris mereka. Oleh karena itu, tujuan penelitian ini adalah untuk menginvestigasi jenis-jenis teknologi yang digunakan oleh siswa SMA dan persepsi mereka terhadap penggunaan teknologi dalam pelajaran bahasa Inggris. Pendekatan mixed method digunakan dalam penelitian ini untuk memperoleh data yang lebih komprehensif dan representatif. Hasil penelitian ini menunjukan bahwa ada delapan aktifitas siswa yang melibatkan teknologi yang sering mereka gunakan. Yaitu $M P_{3}$ player, internet browser, telepon seluler, situs jejaring sosial, dan televisi. Seluruh responden setuju bahwa penggunaan teknologi dalam pelajaran bahasa Inggris sangat efektif. Beberapa keuntungan pemanfaatan teknologi dalam pelajaran bahasa Inggris ditemukan dalam peneitian ini. Akan tetapi beberapa kendala juga ditemukan. Kendala yang paling mengganggu yang dihadapi oleh para siswa adalah akses terhadap fasilitas internet. Mereka juga kekurangan informasi tentang jenis-jenis produk teknologi yang berguna untuk digunakan dalam pelajaran bahasa Inggris.
\end{abstract}

\begin{abstract}
Various informations and knowledge including English lesson can easily be accessed. It gives a large opportuniy to the students to take benefits from the use of technology to up grade their English ability. However, most of EFL students seem only use technology for entertainment needs rather than for learning English. Therefore, the objectives of this research are to investigate the kinds of technology tools used by high school students and their beliefs toward the use of technology in English lesson. Mix method approach is used in this research to gain more comprehensive and representative data. The results show that there are eight activities that involve five kinds of technology that the students frequently used. Those tools are $M P_{3}$ player, internet browser, cellphone, social networking site, and television. All respondents agree that the use of technology in English lesson is effective. Some advantages of using technology in English lesson appear in this research. However, some barriers or problems also found. The most disturbing barrier faced by the students is the access to internet. They also lack of information of useful technology tools which are possible to be used in English lesson.
\end{abstract}

${ }^{\otimes}$ Corresponding author:

Address: Jl. Dr. Setiabudhi No. 299, Kota Bandung,

Jawa Barat, 40154

E-mail: anggi_gusman@student.upi.edu
(C) 2018 Universitas Negeri Semarang p-ISSN 2252-6447 e-ISSN 2527-4597 


\section{INTRODUCTION}

Technology can be defined as everything that people have produced to shape their environment, from individual tools which are used in their daily life to the systems and institutions which guide and define our societies (Barrs, 2011). Technology develops very fast at this era. It helps people to be easier in doing almost all things in all aspects of human life. Education as one of the most important part of human life also affected by the growth of technology. Technology also enables people to do everything faster. There is no doubt about the role played by the new technologies in education today. Teaching and learning of English as part of education process are benefited with technology. Information can be access wherever and whenever fast and easily including information regarding English lesson and knowledge which help the success of teaching-learning. So, there is a large possibility for students to access new knowledge about English lesson by using technology to up grade and enrich their English ability. However, most of EFL students seem only use technology for entertainment needs and fun rather than for learning English.

Furthermore, teaching and learning in $21^{\text {st }}$ century need learning skills that go beyond the four common skills which usually become the main focus of language teaching-learning (listening, speaking, reading, and writing). Nowadays the teaching-learning focus on learning and innovation skills such as critical thinking, creative thinking, communicating and collaborating (Trilling \& Fadel, 2009). Further they argue that the world of work demands experts with high level of critical thinking, the ability to respond to complex communication, continually produce new ideas, products and services for the global marketplace, high level of imagination, and show the ability to work effectively and respectfully in different teams.

Today's students are not similar with the students in the past. They were born in a digital and technologies era as an integral part of their lives from the beginning. Digital technologies surround them and they spend a lot of their time watching television, using smart phones, playing games, surfing the internet, and etc. Today's students prefer to take a snapshot using their smart phone or tablet PC rather than copying down notes written on the whiteboard when come into the classroom, post their updates and messages to Facebook rather than having face-to-face conversation in the class, use Google to search the Internet rather than going to the library to search for information, in short, the thinking and learning approaches of today's students have radically changed (Yong \& Gates, 2014).

The remarkable development of newer technologies has changed the tradition of English teaching drastically. Teaching Methodologies and strategies have been developed in relevance with the newest technology (Ramamuruthy \& Rao, 2015). Technology has a power to attract the language learners' attention (Pun \& Campus, 2013). Getting students' attention is one of the key success of English teachinglearning since it will reveal students curiousity regarding the lesson. The growth of technology should be seen by teachers as a great opportunity to be easier to deliver the knowledge and skills of English. The use of technology, especially Internet in the ESL classrooms helps students to develop their language skills i.e listening, speaking, rading, and writing (Kasapoğlu-Akyol, 2010).

Nowadays technology grows so fast and give impacts to the education process especially at schools. The investment of schools in technology is increasing significantly. The emergence and development of multimedia technology and its application for teaching, featuring visual, audio, animation effects comes into full play in English class teaching-learning and sets a favorable platform for reformation and exploration on English teaching model in the new era with the fast advancement of science and technology. Multimedia technology plays an effective and positive role in promoting activities and initiatives of student and teaching effect in English class has been proven by the development (Shyamlee, Skills, \& Vidyanagar, 2012). Some empirical studies about the use of technology for English development have been done by many researchers around the world (e.g. Abukhattala, 2016; Kennedy, Judd, Churchward, \& Gray 2008; Kızll, 2017; Ko, Thang, \& Ou, 2014; Li, 2016; Sabti \& Chaichan, 2014; Thompson, 2013).

All education stakeholders i.e. researchers, educators, policy-makers, and parents are exploring the best ways for technology integration in classrooms to improve teaching and learning ( $\mathrm{Li}, 2016)$. Teachers and their students are two important stakeholder groups that directly involved at the attempts of technology integration into schools. Their perceptions and views must be totally understood before conducting any initiatives and actions of teaching learning 
improvements. Furthermore, the study of students' recent technological experiences will have implications for ways in which technology could potentially be controlled in pedagogically sound ways to improve teaching and learning (Kennedy et al., 2008).

At this digital era, the emergence of new technological tools, such as computers, Internet, Smartphone and many more has triggered the gradual development of new teaching and learning methods and strategies in English as a Foreign Language (EFL) classrooms. A whole new dimension has been opened by the technologies in the investigation of the issue of teaching effectiveness of English (Sabti \& Chaichan, 2014). Technology has been used in all aspects of human life. It has affected the education especially in teaching and learning process. Technology provides so many choices that enable to make teaching more interesting and also make teaching more productive in terms of progress and improvements. Technology is one of the most influencial factors leading both social and linguistic change.

Moreover, technology is utilized for the fulfillment of today's styles, it satisfies both auditory and visual senses of the students (Shyamlee, et al., 2012). Graddol (in Shyamlee, et al. (2012) proposes that

Technology lies at the heart of the globalization process; affecting education work and culture. The use of English language has increased rapidly after 1960. At present the role and status of English is that it is the language of social context, political, sociocultural, business, education, industries, media, library, communication across borders, and key subject in curriculum and language of imparting education.

In various degrees to language learning situation, there are many techniques are applicable. Some of them are useful for teaching business English, spoken English, reading, listening or interpreting, and some are for testing and distance education. Shyamlee et al. (2012) says that the principle of teaching should be aimed to appreciate new technologies in the areas and functions in which they provide something more quickly and effectively new meaningful thing and never let machines takeover the role of the teacher in teaching-learning or limit functions where more traditional ways of teaching are superior.

English as Foreign Language learners have opportunities to use various technology tools which possible to support English learning nowadays. The tools and resources which have been created on the world wide web (whiteboard, "plug-in" technologies, streaming, and conferencing, etc.) provide big chances for developing language use through multimodal channels (listening, reading, speaking, writing, and communicating) (Yang, 2001). Moreover, some researches show that Mobilephones, Smartphones, and Computers are the common tools which are frequently used by students and teachers (Leis, Tohei, \& Cooke, 2015; Mustafizur, 2013; Farivar, et al., 2015; Ramamuruthy \& Rao, 2015).

According to Soska (in Kasapoğlu-Akyol, 2010) some other technology can be used for language learning are interactive audio, interactive videodisc, local area networks, CD-ROM discs, hypermedia and telecommunications. Furthermore, he proposes that educational technology can help ESL learners to develop their speaking, writing, reading, and listening skills. Databases and spreadsheets such as Microsoft Excell and Google speadsheet can provide direct experience in organizing and finding information, and developing problem-solving skills as well. Also, word processors are very good means to develop writing ability and to motivate students to write further.

Some barriers of using technology in English lesson found by some researchers based on their studies. A study conducted by Sabti \& Chaichan (2014) to Saudi Arabia EFL learners found that one of the most important aspects of the obstacle that students face in learning English is reliance on the conventional model eventhough schools in Saudi Arabia look for progress in relation to the development of educational process by providing the technical devices. However, students still rely on the textbooks used and taught as the common resource by English teachers, which are distributed in the form of handouts. This reliance may be potential to cause lack of self-confidence, motivation and interest to practice English learning activities in the clssroom and to use English in learning environment. Another significant aspect of the problem is not enough exposure to computer technologies, which deters full utilization of computer technology devices by many Saudi EFL learners.

Some advantages of using technology in learning English proposed by Wang (2005). He said that there are many benefits of technology integration in learning especially for EFL students in the classrooms. In order to be able to 
develop their all language skills (listening, speaking, writing and reading). The students of English language often use computers, improve their language skills use Internet, software programs to check their work and correct themselves, publish their work, e-mails to search information, read technology texts, join in threats, communicate each other even worldwide.

Furthermore, he explains that besides many advantages which can be gain from the use of technology, there are also some disadvantages of integrating technology in the classroom. Some of the disadvantages are the tremendous start up expenses, the issues of copyright, materials which are objectionable and other disadvantages of technology that are potential to appear. Many researches have been done regarding the effectiveness of and better strategies for integrating technology into classroom to make more successful result.

Moreover, many other advantages of using technology in English lesson as proposed by some researchers. Lee et al. (2016) said that one of the benefits of using computer technology for language learning in the modern world is that language learners can choose the learning materials they are interested in or that are useful to them available at computers or accessible via the Internet at school or at home with or without teacher help. So, technology is able to trigger and enable English language learners to learn English autonomously.

Abukhattala (2016) proposes four benefits of technology in classrooms, i.e. (1) the novelty of the new technologies or experience of the learners toward those technologies in the classroom is able to encourage learners' engagement and motivation in fulfilling tasks, (2) in language learning and teaching, the technology invention and development in the education field have accelerated a change from teacher-centered to learner-centered approaches, (3) the use of technology in the class enables learners to assess their own work in a more meaningful way, become more aware of the quality of their work and accept feedback more willingly, and (4) the support of collaboration and communication in learning activities.

Prensky (2001) proposes that people born in or after 1980 are 'digital natives', means that they are really familiar with new technologies. While those who born before 1980 are 'digital immigrants', many of them find difficulties in using technology. Most students in different le- vels of education seem depend on their teachers in the classrooms and there is no any chance for the students to control their own learning process. Very seldom the students gain the information and knowledge by themselves. Most of the time the teachers are the one who provide all the information and knowledge. There is a crucial need for students to be responsible for their own learning.

Therefore, it is important to help students to be aware of the importance and significance of independent learning outside the classroom, so that they get the habit of learning autonomously and continuously, and keep it by themselves after they have finished their formal studies (Farivar \& Rahimi, 2015). Some researches about the use of technology such as Computer Assisted Language Learning (CALL), Mobile Assisted Language Learning (MALL), Smartphone Assisted Language Learning (SPALL) and etc indicate that technology can foster students' learner autonomy (Leis et al., 2015; Mustafizur, 2013; Farivar et al., 2015; Ramamuruthy \& Rao, 2015).

The integration of internet technology has also promoted a new field for English learning autonomy which is becoming more and more popular in the field of education today. Learning English on the Internet enables to create effective and high-quality achievement in personal or mass English learning. Many people especially education doers begin to pay attention to internet learning and investigate how to make a full use of it (Zhong, 2008).

Ko, Thang, \& Ou (2014) conducted a research that investigated the ICT Use and needs of 'Digital Natives' In learning English at a Taiwanese University. There were 569 'digital natives' students that use technology for English learning and for recreational purposes. They also investigated students perception on the applicability of technological tools such as blogging, Facebook, and Skype for English Language teaching and learning. The findings of the study showed that despite the students showed positive response with regard to the use of technologies for language learning, their use of technological tools for academic learning seemed very limited rather than for recreational purposes.

They also prefer to use similar well-established technologies rather than new and emerging technologies for either learning or recreation need. The students' frequently used technology items and owned by them were mobile phones and laptop. Their mobile phones 
were completed with new and high technology features like $\mathrm{MP}_{3}$ player, video player, and camera. While the amount of the students who have laptop is less than what expected, it was only $69.6 \%$ of total students sample. Technology items which are less popular for all three disciplines are handled computer, portable media player, games console, portable games, and digital camera. There are five tools with the highest score of mean, they were YouTube, Facebook, Online Self-tests/Quizzes/ Practices, Slideshare (e.g. Powerpoint, Prezi, etc.) and Online Assessment Submission. Youtube is the top list with the highest mean score among those tools while Facebook and Online self-tests/quizzes/puzzles following close behind it.

Sabti \& Chaichan (2014) conducted a research about Saudi high school students' attitudes and barriers toward the use of computer technologies in learning English. There are three obstacles that affected Saudi Arabia students detected, they are equipment, motivation and skill. Equipment and motivation get almost equal result. It indicates that it is approximately at the same level in term of effect on the students. Moreover, skill was also becomes one of the barrier for the students. So, their knowledge and experience on how to use the computer tools are limited. This obstacle give more effect to students rather than the other two barriers. Skill is about the knowledge, proficiency, and ability of the students related with the tools. So, the experience and adequate information about computer devices in learning English are gained very limited by the students.

In conclusion, there are so many kinds of thechnology that can be used by EFL students to improve their knowledge and ability in English lesson at this era. Those technology are very useful to help developing students learning autonomy. By using technology they can have access to the new knowledge of English lesson without time and place limitation. So many advantages could be got by EFL students in learning by using technology including English lesson. However, some barriers deter the EFL use of technology for learning. Smart solutions are needed to overcome those obstacles to maximalize the benefits of technology use in English lesson.

Therefore, to understand kinds of technologies used by the students and their beliefs regarding the use of technologies in English lesson is very crucial. Because the informations are needed by the teachers to determine the best technology tools to be used as teaching media. And to design the most suitable interesting teaching activities by using technology. A deep investigation and research to understand students' technological experiences will have clear implications for areas such as student access, equity and transition (Kennedy et al., 20o8). It also will be such kind of important information for education practitioners who involved in teaching and learning practice in the field. Thus, the objectives of this research are to investigate the kinds of technology tools used by high school students and students' beliefs about the use of technology in English lesson.

\section{METHOD}

Mixed method approach design was used in this research, where quantitative and qualitative approaches were apllied. Mixed methods research design can be defined as a procedure to collect, analyze, and "mix" both quantitative and qualitative methods in a single study or a set of studies to understand a research problem (Creswell \& Plano Clark, in Cresswell, 2012). Mixed methods research is practical because it is free for the researcher to use all possible methods to adress research problems (Hamied, 2017).

The total of 167 high school EFL students from six schools in Indonesia were involved in this research. They were taken from different cluster; two schools are from urban area, two schools are from suburban area, and two schools are from rural area, to gain more representative and general result of the study. However, 16 respondents' responses to the questionnaire were incomplete and some were double answers. Those respondents responses were not analyzed in order to gain valid data result. So, 151 data were analyzed in this research. Six students, one from each school, were interviewed to explore their beliefs about barrier and benefits of technology use in English lesson.

Since this research applied mix method, questionnaire and interview were conducted. The questionnaire was adopted from Thompson (2013). It consists of 41 kinds of activities which involve common technologies. The response scale was as follows; 8 = a few times a day, $7=$ about once a day, 6 = a few times a week, $5=$ about once a week, 4 = a few times a month, $3=$ about once a month, 2 = a few times a year, $1=$ never. The specific scale enable the respondents to choose more appropriate scale based on the reality. The 
Figure 1 Kinds of Technology Used by EFL Students

MEAN

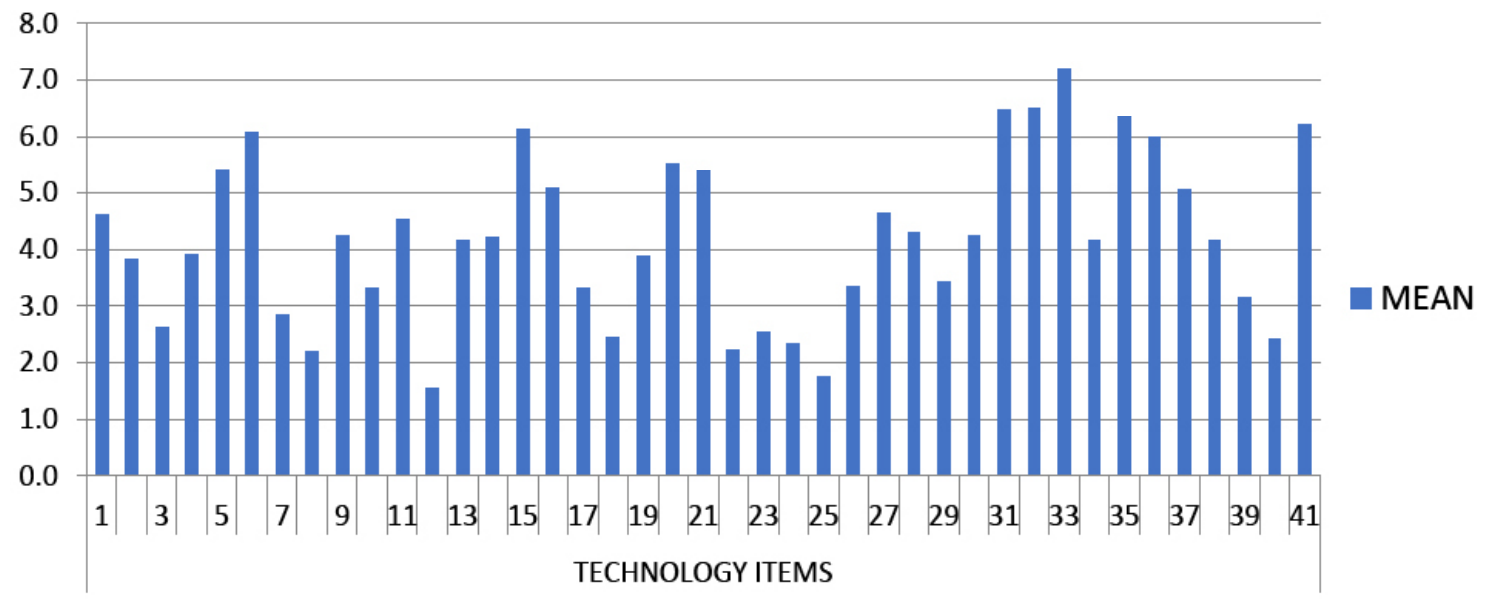

interview questions were adapted from similar journal and syncronized with the context and the information needed for this research to get qualitative data.

Data were collected during April to May 2017. Questionnaire and interview data were taken at the same day in each school. One student from every school was interviewed just after he/ she finished filling the questionnaire. The data collection procedures conducted by the researchers were presented as follows:

1) Targetted schools were determined

2) Researchers start data gathering from one suburban and one urban area schools in 27 April 2017.

3) One other school in suburban area was involved in May 2nd, 2017.

4) One school in urban area was involved in May 3rd, 2017.

5) The last two schools in rural area were involved in May 1oth, 2017.

6) The students' responses regarding the questions in the questionnaire were tallied, they were sum up, then divided by the number of respondents to get the mean of the score.

The data from questionnaire were analyzed and described quantitatively, while the data from interview were analyzed and described qualitatively. The two databases are analyzed separately and then brought together (Creswell, 2014). First, the researchers tallied responses from the questionnaire and transcript responses from interview questions while looking for the patterns which related to the research questions which guide the exploration. Next, I calculated the mean score of each item in the questionnaire to rank the most frequenlty used technology, while the data from the interview response described qualitatively.

\section{RESULT AND DISCUSSION}

In the following section the authors would describe the result of the research and then analyzing it appropriately. Firstly about the various types of technology used by students and secondly about the meanings and facts met by the student on using technology as a tool for their learning activity.

\section{A. Technology Tools Used by High School Students}

The data gained from the questionnaire are adressed to answer first research question, What technology tools do high school students use and how frequently do they use them? The responses from the respondents in each item are sum up, then divided by the number of respondents to get the mean of the score. The result is shown in the figure 1.

As shown in the figure 1, generally Indonesian EFL high school students use all types of technology asked in the questionnaire. However, only eight activities that use technology tools which frequently carried out by them. The eight activities got $>=6$ mean score, it means that they are conducted by the respondents with the range from a few times a week to a few times a day in 
average.

They are ( 1 ) listen to music online or on a computer $\left(\mathrm{MP}_{3}\right.$ player) (mean = 7.2), (2) use the web to look up a fact or answer a specific question (internet browser) $($ mean $=6.5)$, (3) send a text message (cellphone) (mean $=6.5),(4)$ answer a text message (cellphone) (mean $=6.3),(5)$ make or receive a voice call (cellphone) $($ mean $=6.2$ ), (6) check for updates on a social networking site e.g., Facebook, MySpace (social networking site) (mean $=6.1),(7)$ comment on a friend's post on a social networking site e.g., Facebook, MySpace ( social networking site) ( mean $=6.1)$, and (8) use two or more technologies (other than listening to music) at the same time e.g., text friends or watch TV while working on the computer, etc $($ Television $)($ mean $=6.0)$.

From those activities, there are five kinds of technology tools that frequently used by the students $\mathrm{MP}_{3}$ player, internet browser, cellphone, social networking site, and television. We may also conclude that the students in this era are already familiar with technologies. $\mathrm{MP}_{3}$ player, internet browser, cellphone, and social networking site are usually operated in smartphone, tablet, iPad, or computer/laptop.

Researches conducted by Leis et al. (2015); Mustafizur (2013); Farivar et al. (2015); Ramamuruthy \& Rao (2015) also described the use of Smartphones, Computers, and Mobilephones that help English learning process. Moreover, $\mathrm{MP}_{3}$ player, cellphone, and internet browser are technology tools that are also suggested by Soska (in Kasapoğlu-Akyol, 2010), in which he suggests some of the technology tools that could be used by students for English lesson learning, among them, interactive audio, local area networks, and telecommunications. While Yang (2001) proposed that technology tools could be used by students are whiteboard, "plug-in" technologies, streaming, and conferencing.

\section{B. EFL Learners Beliefs Towards the Use of Technology in English Lesson}

With reference to the second question attempted in this research, six students-one student from each school-are interviewed to get qualitative data. The interview questions are developed to see Indonesian EFL learners beliefs towards the use of technology in English lesson. Students responses to the interview are adressed to answer second research question, what are students' beliefs about the use of technology in
English lesson?

Based on the interview, all students agreed that the use of technology in English lesson is effective. However, some barriers or problems found in the use of technology. Only one respondent that come from urban school has no problem with the use of technology. While the other five respondents share equal opinion that they face some barriers in using technology even though they have different obstacles.

Not all students that live in urban area come from economically advantage or rich family. Some students in urban area come from economically disadvantage families. Economic situation may influences students learning process and achievement. As what happen to one respondent from school in urban area, economic reason become the most influence barrier in using technology for English lesson. Free WiFi access can not be accessed everywhere, so, to enjoy internet access the students should use data cellular which must be bought by their own money.

Students coming from low income family should struggle to save extra money to buy data cellular since it is too expensive for them. Rarely they have extra money to buy data cellular. It makes the difficulty to use and access technology such as internet. Meanwhile, the money given by their parent must be used for transportation cost for everyday go to school.

Respondents from suburban area found almost similar barriers in using technology with the previous respondent. They also have problem with the internet access, however, the problems are not caused by the economic reason, but they come from the signal quality of internet network. According to the respondents, the poor quality of internet signal become disturbing barrier for them to be free in using internet based technology. However, they can still enjoy good access in their school where wifi is accessible even though they have to find certain spots.

In some spots of rural area, internet access is still possible to be accessed. However, most of the areas are almost impossible to enjoy internet access. As can be predicted, among others, respondents from rural area get more significant problem with internet access than others. In the interview conducted by the researchers, one respondent from this area expressed problem she faces in using technology. No wifi even in her school can be used, data cellular also can only be 
used in very limited spots with poor quality. She said that her village is an isolated place where there is no internet provider who install the tools of technology to make it easy to access the internet. So, in rural area internet-based technology learning can not maximally be applied because of the absence of the facilities.

In conclusion, the access to the online websites and resourches in internet is still unequally distributed in all areas. It becomes the common barrier in using internet-based techology for English lesson faced by the students. Besides there is also other barrier such as economic factor. Meanwhile, non-internet-based technology tools such as television, cellphone, $\mathrm{MP}_{3}$ player, tape recorder, and etc can still be used.

Besides those barriers, many benefits can be got by the respondents from technology use in English lesson. All respondents from all areas share equal opinion that technology help them so much to make it easy to translate either English to Bahasa Indonesia or Bahasa Indonesia to English. Technology also make them easy to get new informations and knowledge including English materials such as English text. Besides online technology, film and offline dictionary also useful for English lesson. They can get more vocabularies that they do not get in the classroom from their teacher as said by a respondent from urban school. Technology also enable them to get free, easier and faster access to gain more unlimited knowledge from unlimited resources.

Wang's (2005) investigation about the benefits of the use of technology in English lesson indicates almost similar result with the finding of this study. Some of his findings are in order to be able to develop their all language skills the students of English language often use computers, improve their language skills use Internet, software programs to check their work and correct themselves, publish their work, e-mail to search information, read technology texts, join in threats, communicate each other. Moreover, Lee et al. (2016) said that one of the benefits of using computer technology for language learning is that language learners can choose the learning materials they are interested in or that are useful to them available at computers or accessible via the Internet at school or at home with or without teacher support. Result of their research is also in line with current finding.

Furtheromore, problem that influence the beliefs of the respondents and impede their use of technology especially online resources and the Internet in learning English also identified. It seems that lack of motivation becomes an obstacle that influence students use of technology. The problems that influence the beliefs of the respondents and restricted their use of technologies for learning English were essential barriers, including the lack of motivation.

From the finding, it seems that the students only pay a bit attention to the technology use for English lesson. This condition clearly refers to the inner aspect that respondents have. The common benefit of technology based on the respondents point of view is to translate, some of respondents looked confuse when they were asked about other benefits. Since some of them might used technology in English lesson only to translate.

The lack of information of useful technologies which possible to be used in English lesson also seems become one of the problem in students' use of technology. Therefore, English teachers should guide the students and direct them to the good sites for learning English. Teacher should endorse useful technologies or online websites that enable students to gain extraknowledge autonomously. Teachers also should be able to encourage and motivate students to use technology as the tool and source of gaining knowledge including English lesson.

The creativity of teachers to create students learning autonomy through the use of technology for learning is required. Along with this finding, a study conducted by Sabti \& Chaichan (2014) showed that besides students' reliance on the conventional model in learning English, another significant problem is not enough exposure to computer technologies, which deters full utilization of computer technology devices by many EFL learners.

Difficult issue in accessing internet in rural area makes it almost impossible for students to get helpful information and online technology facilities. A large amount and unlimited access to the new and updated information and knowledge of English language are provided by the internet technology. Difficult access to this kind of technology could reduce the students readiness and confidence to face global rivalry. To solve this problem, government should pay more attention to the availability of technology facilities at schools in all vital areas especially in rural areas. At least government could facilitate rural schools with $\mathrm{WiFi}$ in order students to get internet access although not as much as students 
in urban or suburban areas, where they can access internet and many other kinds of technologies everywhere easily.

The availability of technologies that support English lesson is absolutely crucial in this era, since information and technology develop so rapidly. Unless students in rural schools will always left behind the students in urban schools. This is also related to the equality in education to ensure that every student has similar right in getting good education. The students that come from economically disadvantage family also should be taken into account as they who must be cared by the government. The Government and schools principals and officials should make sure that the students get scholarship which cover their possibility to get good technology facilities.

\section{CONCLUSION}

There are eight activities that use technology tools which frequently carried out by the students. They are (1) listen to music online or on a computer ( $\mathrm{MP}_{3}$ player), (2) use the web to look up a fact or answer a specific question (internet browser), (3) send a text message (cellphone), 4) answer a text message (cellphone), (5) make or receive a voice call (cellphone), (6) check for updates on a social networking site e.g., Facebook, MySpace (social networking site), (7) comment on a friend's post on a social networking site e.g., Facebook, MySpace (social networking site), and (8) use two or more technologies (other than listening to music) at the same time.

It can be seen from above activities that there are five kinds of technology tools that frequently used by the students $\mathrm{MP}_{3}$ player, internet browser, cellphone, social networking site, and television. We may also conclude that the students in this era are already familiar with technologies. $\mathrm{MP}_{3}$ player, internet browser, cellphone, and social networking site are usually operated in smartphone, tablet, iPad, or computer/laptop.

More over, all students agreed that the use of technology in English lesson is effective. However, some barriers found. Only one respondent, come from school in urban area, has no problem with the use of technology. While the other five respondents share equal opinion that they face some barriers in using technology. Access to internet appeared as the most disturbing barrier faced by the students. They also lack of information of useful technologies which possible to be used in English lesson.

\section{REFERENCES}

Abukhattala, I. (2016). The use of technology in language classrooms in Libya. International Journal of Social Science and Humanity, 6(4), 262-267. https://doi.org/10.7763/IJSSH.2016. V6.655.

Barrs, K. (2011). Mobility in learning: The feasibility of encouraging language learning on smartphones. Studies in Self- Access Learning Journal, 2 (3), 228-233.

Creswell, J. (2012). Planning, conducting, and evaluating quantitative and qualitative research; Fourth edition. Boston: Pearson Education, Inc.

Creswell, J. (2014). Research design : qualitative, quantitative, and mixed methods approaches. California: Sage Publications.

Farivar, A., \& Rahimi, A. (2015). The impact of CALL on Iranian EFL learners' autonomy. Procedia - Social and Behavioral Sciences, 192(July), 644-649.

Hamied, F. (2017). Research Methods: A guide for firsttime researchers. Bandung: UPI Press.

Kasapoğlu-Akyol, P. (2010). Using educational technology tools to improve language and communication skills of ESL students. Novitas-ROYAL, 4(2), 225-241.

Kennedy, G. E., Judd, T. S., Churchward, A., \& Gray, K. (2008). First year students ' experiences with technology : Are they really digital natives? Australasian Journal of Educational Technology, 24(1), 108-122.

Kızıl, A. Ş. (2017). EFL learners in the digital age: An investigation into personal and educational digital engagement. RELC Journal, 48(3), 373388.

Ko, C.J., Thang, S. M., \& Ou, S. (2014). Investigating the ICT use and needs of "digital natives " in learning English at a Taiwanese university. International Journal of Web-Based Learning and Teaching Technologies, 9(2), 32-45.

Lee, C., Yeung, A. S., \& Ip, T. (2016). Use of computer technology for English language learning: Do learning styles, gender, and age. Computer Assisted Language Learning, 29(5), 1035-1051.

Leis, A., Tohei, A., \& Cooke, S. (2015). Smartphone assisted language learning and autonomy. International Journal of Computer-Assisted Languange Learning and Teaching, 5(3), 75-88.

$\mathrm{Li}, \mathrm{Q}$. (2016). Student and teacher views about technology: A tale of two cities? Journal of Research on Technology in Education, 39(4), 377-397. https://doi.org/10.1080/15391523.200 7.10782488 .

Prensky, M. (2001). Digital natives, digital immigrants. On the Horizon. MCB University Press, 9(5). 1-6. 
Pun, M., \& Campus, P. N. (2013). The use of multimedia technology in English language teaching: A global perspective. Crossing the Border: International Journal of Interdisciplinary Studies, $1(1), 29-38$.

Rahman, M.M. (2013). CALL in promoting EFL learner autonomy at the tertiary level in Bangladesh. Proceeding in ICTERC 2013, 71-80.

Ramamuruthy, V., \& Rao, S. (2015). Smartphones promote autonomous learning in ESL classrooms. Malaysian Online Journal of Educational Technology, 3(4), 23-35.

Sabti, A. A., \& Chaichan, R. S. (2014). Saudi high school students' attitudes and barriers toward the use of computer technologies in learning English. SpringerPlus, 3:46o, 1-8.

Shyamlee, S. D., Skills, C., \& Vidyanagar, V. (2012). Use of technology in English language teaching and learning : An analysis. International Conference on Language, Medias and Culture, 33, $150-156$.
Thompson, P. (2013). The digital natives as learners : Technology use patterns and approaches to learning. Computers $\mathcal{E}$ Education, 65, 12-33. https://doi.org/10.1016/j.compedu.2012.12.022

Trilling, B. \& Fadel, C. (2009). 21st Century Skills: Learning for Life in Our Times. San Fransisco, U.S.A.: Jossey-Bass.

Wang, L. (2005). The advantages of using technology in second language education. T.H.E. Journal, 32 (10), $1-6$.

Yang, S.H.U.C. (2001). Language learning on the world wide web : An investigation of EFL learners ' attitudes and perceptions. Educational Computing Research, 24(2), 155-181.

Yong, S., \& Gates, P. (2014). Born digital: Are they really digital natives? International Journal of e-Education, e-Business, e-Management and e-Learning, 4(2), 150-155. https://doi. org/10.7763/IJEEEE.2014.V4.311.

Zhong, Y. (2008). A Study of autonomy English learning on the internet. English Language Teaching, 1(2), 147-150. 